\title{
Ressonâncias do euclidiano consórcio entre ciência e arte no Grande Sertão rosiano
}

\author{
RESUMO
}

\section{Gregory Magalhães Costa}

gregorymagalhaescosta@gmail.com Universidade Federal do Rio de
(UFRJ), Rio de Janeiro, Brasil.
O projeto literário de Euclides da Cunha consiste no consórcio entre ciência e arte, como ele próprio revelou a José Veríssimo. Essa união pressupõe vigor de imaginação poética estruturado sob um rigor crítico científico - como aquelas partículas quânticas que mutuamente se implicam, observadas por llya Prigogine. Por isso, sua obra poética se assemelha a um ensaio sócio-histórico. Esse drama fáustico se expressa no Grande sertão de Guimarães Rosa na luta civilizatória de Zé Bebelo contra a primitiva dicção poética dos demais chefes jagunços, liderados por Joca Ramiro e Hermógenes. O canto poético de Riobaldo é eivado de reflexões filosóficas de rigor científico, como a própria disposição crítica de sua narração catártica, que visa curar sua dor de amor pela morte de Diadorim. Assim, pelo método da poética comparada, com embasamento crítico-literário e científicofilosófico, pretende-se demonstrar como Euclides cunha o consórcio entre ciência e arte e sua herança na obra de Rosa.

PALAVRAS-CHAVE: Ciência. Arte. Ficção. Literatura. 


\section{INTRODUÇÃO}

Todo escritor literário parece possuir um projeto poético: o de Gregório de Matos Guerra é a crônica satírica da Bahia seiscentista; o de Claudio Manuel da Costa, a dissonância entre singeleza da alma e aspereza do meio e do amor; o de José de Alencar, forjar a identidade nacional pela harmonia mítica e ingênua do branco com o índio; o de Machado de Assis trata de converter o leitor de literatura mimética em leitor de literatura poética. $O$ projeto literário de Euclides da Cunha consiste no consórcio entre ciência e arte, como ele explica em carta a José Veríssimo, ao afirmar que se trata da "tendência mais elevada do pensamento humano" (1997, p. 143/144).

Essa elaboração de uma obra artística (nesse caso, uma narrativa ficcional) misturada a uma nova concepção de ciência, que não exclui a invenção, imaginação e criatividade, levou a obra maior de Euclides da Cunha, Os sertões, a ser compreendida pelos críticos literários ora como ensaio científico, ora como narrativa ficcional, ora como ambas as coisas. Aderem à tese do ensaio científico críticos como Franklin de Oliveira e Luiz Costa Lima; entusiasta da teoria da narrativa ficcional é Afrânio Coutinho, que se diz inspirado por João Ribeiro; defensores da visão euclidiana do consórcio entre ciência e arte são Antonio Candido, Gilberto Freyre, Berthold Zilly e Ronaldes de Melo e Souza.

Seguindo a sugestão das situações narrativas delineadas por Franz Stanzel (1971), assim como a construção dos monólogos narrativos por Dorrit Cohn (1978), podemos deduzir que a especificidade da ficção literária narrativa é a dupla mediação da linguagem entre narrador e personagem, o que leva Ronaldes a bater o martelo a favor da tese de que Os sertões constituem uma obra de arte ficcional que não deixa de se consorciar com a ciência. Euclides acaba prenunciando todo o desenvolvimento da ciência do século XX, ao advogar pela indissociabilidade entre ciência e arte.

Realmente, nenhuma outra ficção, artística ou científica, possui a dupla mediação narrativa entre personagem e narrador. Antes de chegar ao leitor, a estória passa ao menos por esses dois "filtros": o narrador e o personagem. Do mesmo modo, a única fiç̧ão que possui a mediação do eu lírico é a poesia; a mediação única do personagem, o drama; a mediação do cinema se dá pelo movimento da câmera; e assim por diante. A ciência clássica nega seu caráter ficcional, afirmando-se como verdade; já a ciência contemporânea relativiza isso, instaurando o princípio da incerteza e da dúvida, da criatividade como princípio universal e da observação científica implicando a imperfeição de sentidos do observador, incluindo sua instância em seu processo.

Ilya Prigogine escreveu uma obra clássica, A nova aliança, a respeito da evolução da ciência, que passou a incluir processos típicos da natureza e do universo, como a constante criação, invenção, imaginação. A nova aliança consiste numa espécie de retorno à primitiva união entre ciência e natureza. Como a arte se processa por princípios equivalentes aos da natureza, a união entre ciência e natureza implica irrevogavelmente o consórcio entre ciência e arte, pela inclusão inevitável da criatividade, princípio telúrico e cósmico por excelência: 
práticas cognitivas, nossa ciência ocupa a posição singular de escuta poética da natureza - no sentido etimológico em que o poeta é um fabricante -, exploração ativa, manipuladora e calculadora, mas doravante capaz de respeitar a natureza que ele faz falar (PRIGOGINE, 1984, p. 215).

Na sua reflexão crítica sobre ser e devir, permanência e mudança, o físico russo conclui: "Sem dúvida a ciência é uma arte de manipular a natureza. Mas é também um esforço para compreender, para responder a algumas questões que, de geração em geração, alguns homens não cessaram de colocar a eles mesmos" (PRIGOGINE, 1984, p. 203). A ciência não consiste só em elaborar questões e soluções novas, mas de repensar e renovar questões antigas tidas como ultrapassadas. Elas sempre acabam retornando e, em geral, se mostram o meio mais profícuo de gerar novidade.

A ciência não só manipula a natureza e a compreende, como passa a se processar pelo seu princípio básico da criatividade, da brotação incessante, ligando-se à physis grega (processo autônomo de transformação). A novidade científica brota da renovação da visão antiga. Foi isso que Einstein quis fazer quando, em sua teoria da relatividade, acabou reinserindo a instância do observador na natureza por ele observada. A natureza observada aos poucos voltava à sua antiga aliança com a instância do observador. Nesse sentido, a defesa de Prigogine em relação à ciência se assemelha à de Euclides e à de Rosa em relação à arte.

Euclides da Cunha não deixa de abordar poeticamente o tema da atuação da natureza sobre o homem e do homem sobre a natureza. Sua obra já prenunciava a retomada do pacto entre homem e natureza, ciência e arte. Essa nova aliança, sobre alicerces bem antigos, consiste em reconhecer que a observação da natureza se concilia com a visão do observador. Tal visão dialética derruba qualquer princípio de linearidade positivista ou determinação naturalista.

No final da primeira parte de seus sertões plurais, "A terra", Euclides encena a dialética da construção e extinção de um deserto, ambas por um agente geológico inesperado - o homem -, desiludindo a expectativa do leitor. Para mostrar esse debate e embate, o observador itinerante apela para sua máscara de investigador dialético e mostra sua visão da união entre a fantasia da arte com o rigor da ciência: "Imaginamo-los há pouco, numa retrospecção em que, certo, a fantasia se insurgiu contra a gravidade da ciência, a emergirem geologicamente modernos, de um mar terciário" (1984, p. 33).

Com base nessa reflexão, o personagem-narrador veste a máscara de historiador irônico e denuncia o homem como um histórico fazedor de desertos, talvez mais do que todos os demais agentes geológicos. O mesmo homem que tem o potencial de atuar tão negativamente sobre a natureza tem também a oportunidade de a restaurar, segundo o movimento dialético proposto por Euclides. Ele comenta como, depois de tomar Cartago, os romanos tiveram de vencer também a natureza, manipulando-a com seu engenho para extinguir o deserto, tornando-o novamente habitável. Como duas partículas que coexistem, o martírio da terra implica o do homem e vice-versa. 
O movimento dialético da ciência é o de se reabilitar por meio da natureza e da arte. A ciência tradicional do céu inteligível platônico ou da física aristotélica das trajetórias astronômicas divinas e imutáveis, que havia desencantado o mundo por entendê-lo divino e estático, é reencantado ao reconhecer a plena diversidade do mundo: certo grau de indeterminismo, de incerteza, que assimila toda a criatividade proliferante da natureza e da arte como princípios constitutivos de tudo, se tornando princípio científico de composição e elaboração - acaso e necessidade, nas palavras de Prigogine. Para ele, não se pode descrever a natureza "do exterior", como simples espectador.

Ele destaca que "numerosos críticos da ciência moderna acentuaram o caráter de passividade e submissão que a física matemática empresta à natureza que descreve" (1984, p. 205). Desse modo, a ciência contemporânea se voltou para entender a natureza em toda a sua atividade e complexidade, não mais como um objeto estático e passivo. A ciência contemporânea passou a entender a natureza como algo vivo e ativo, exatamente como os nativos americanos. Por ironia, foi essa compreensão avançada da natureza por parte dos ameríndios que serviu de pretexto para os europeus dizimá-los, considerando moderno o entendimento europeu atrasado de uma natureza autômata, objetificada, previsível.

As mônadas de Leibniz acabam demonstrando-se incompatíveis com a realidade e com a natureza. A ciência tributária da metafísica platônica percebe que precisa se tornar dinâmica e múltipla, para poder compreender o mundo e explicá-lo. Porém, sua explicação racional é resultado de todo um processo de construção imaginativa. A própria teoria monádica de Leibniz foi criada e imaginada por ele, tanto que não corresponde à realidade. Numa crítica mais radical e ácida, podemos considerá-la como "delírio lógico" e incluí-la na categoria do Realismo fantástico. Vale reassaltar que a tese leibniziana tem sua utilidade, ao servir de parâmetro ideal e base comparativa para as reflexões do mundo real.

$\mathrm{Na}$ contemporaneidade, a ciência também teve sua expectativa desiludida quando "descobrimos agora a violência do universo, sabemos que as estrelas explodem e que as galáxias nascem e morrem" (Prigogine, 1984, p. 206). Aquele equilíbrio clássico, que já havia caído na arte, cai também na esfera da ciência. $O$ mundo e o universo são muito mais barrocos, proliferantes, violentos e caóticos do que supunha a razão pura. Ele possui pulsares e quasares transbordantes, buracos negros inimagináveis, forças magnéticas tão invisíveis quanto determinantes e o potencial incalculável de muitos Big Bang.

A arte descobriu esses princípios antes da ciência, como soe acontecer. Soa o alarme da ciência: agora ela busca seu caráter quântico para se reabilitar, fugindo daquele impávido demônio de Laplace, capaz de calcular o passado e o futuro das partículas, ainda que meramente pela análise de suas trajetórias. O próprio Laplace acabou concluindo que seu demônio não era capaz de calcular tudo e que o futuro é imprevisível. Muitas coisas fogem ao alcance da ciência. Quanto mais ela admite isso, mais espaço tem para inovar e avançar.

A trajetória da física clássica se soma ao processo da moderna; a dinâmica à termodinâmica; o ser ao devir; a permanência à mudança. Corpo e onda são indistinguíveis, como matéria e espírito. No fim, a síntese não consiste na supremacia de um dos lados - pois eles são inseparáveis e equivalentes -, nem na sua soma, tampouco na sua mistura, mas na sua organização caótica ou no seu caos organizado. A síntese tem múltiplas possibilidades, decididas por acaso e 
necessidade, que se manifestam para nós apenas no seu aspecto de probabilidade dentro da sua imprevisibilidade. Os processos do mundo e do universo são mais móveis, mutantes e complexos do que se pensava.

É exatamente isso que sugere "A terra", primeira parte dos sertões plurais de Euclides. Ali se encena todo um movimento telúrico de tensão dialética dos elementos minerais e naturais opostos, com seu embate formando toda a terra. $O$ encontro de colossais placas tectônicas e titânicas explosões vulcânicas elevaram as terras da América, deixando por toda a parte indícios do mar cretáceo que foi como a água salgada do Titicaca, a mais de 4.000 metros de altura, ou o Salar de Uyuni (Deserto do Sal), ou fósseis de peixes da época cretácea. Euclides não chama essa visão, da origem das terras americanas, de verdade científica, mas de "sonho de geólogo" e de "sugestão empolgante".

A disputa de teses a respeito da origem do mundo - entre marítima ou vulcânica, netunismo ou vulcanismo - é antiquíssima. Goethe toma parte na disputa em seu Fausto. Na segunda parte da tragédia, o universal romântico alemão realiza a moderna plasmação mitopoética de teorias científicas contemporâneas, embora de origem muito antiga. Ele põe em cena essa contenda geológica entre o "vulcanismo" de Mefisto e o "netunismo" de Fausto. Chegou a hora de a arte encenar a ciência, sem se deslocar da alquimia, da magia, da constante transformação.

O diabo começa defendendo sua concepção vulcânica de mundo: "Em que arde fogo cêntrico, abraseando/ Voraz conflagração em torno acesa,/ Vimo-nos, na luz exagerada// Do alto e baixo a expelir bofes medonhos,/ $O$ inferno encheu de enxofre, ácido e azia,//Rebentou afinal a térrea crusta". Sem distinção entre mestre e aprendiz, mas num diálogo entre iguais, Fausto retruca: "Quando em si se esculpiu a natureza,/ Arrematou o globo com pureza;/ Com píncaros e abismos se encantou,/ Rochas, montanhas, morros alinhou/ Em elos de colinas descompôsse,/ Que em queda suave para o vale trouxe./ Por seu prazer tudo verdeja e cresce,/ De absurdos torvelinhos não carece" (2011, p. 467/468).

A visão fáustica da origem marítima do mundo inclui o entendimento grego de natureza enquanto physis: "Por seu prazer tudo verdeja e cresce". Essa parece ter sido a perspectiva de mundo encantado que deslumbrou Euclides da Cunha. $\mathrm{Na}$ sua formação e transformação poética das terras da América, ele evoca claramente o netunismo de Fausto, dando uma concepção marítima para seus sertões, sem excluir o vulcanismo das explosões monumentais, expelindo o magma que ajudou a moldar a terra, inclusive, fertilizando-a.

Ronaldes ressalta que a origem marítima da terra se compagina na poesia homérica, no pensamento pré-socrático e até anteriormente. Para ele, "o mar simbolicamente se representa como expressão do ato genesíaco" (2009, p. 21/22). A aliança entre ciência e arte deve incluir o pacto entre netunismo e vulcanismo, embora Euclides pareça privilegiar a origem pelo mar. Ressaca no fundo da alma de Capitu expressa em seu olhar, ou no mar de amor que é a sertaneja Diadorim. É Tristão de Ataíde quem ressalta que Rosa uniu "o espírito telúrico e o espírito oceânico" (1983, p. 142).

É interessante notar que, em Nuestra tierra, quase 40 anos depois do sucesso euclidiano, Emilio Romero lança entendimento semelhante ao sertanejo. Para ele, a costa do Peru é resultado de uma luta tremenda dos elementos. Em sua visão poética da origem da América (visão essa que entendemos mais se aproximar da 
realidade), ele compreende que a própria terra faz sua biografia com o estrondo dos vulcões, a tremenda força dos rios e a velocidade dos ventos. A terra sertaneja de Euclides também faz sua própria biografia, ela chega a se arregimentar para lutar ao lado dos excluídos, dificultando ao máximo o avanço dos opressores. Essa compreensão se reflete em Guimarães Rosa, quando, numa espécie de prosopopeia, a terra é tão importante que o morro dá recado aos heróis, salvando suas vidas.

Emilio Romero lembra ainda que a cordilheira dos Andes é a mais grandiosa formação montanhosa do planeta. Ela atinge do gelo glacial à floresta amazônica, passando por litorais, desertos, vales, barrancos, penhascos, abismos etc. Ele a interpreta como "uma tragédia grandiosa para se chegar a deus" (1941, p. 39). Como Euclides, Romero delineia a consonância da luta da terra com a do homem: "Cada povo da América em sua pátria tem uma grande batalha a vencer, a missão que a cada geração nos lega o destino pela formação da pátria" (1941, p. 7).

A narrativa ficcional de Euclides envereda pela formação da pátria por meio do genocídio daqueles que o narrador mostra possuírem o cerne da identidade nacional, demonstrando ser um ato suicida em relação à nossa nacionalidade. Talvez por isso, o historiador irônico termine a obra refletindo criticamente que a guerra de Canudos foi um crime contra a nacionalidade. Inclusive, a terra ajudou o sertanejo a se constituir como cerne da nossa identidade pátria, pois o isolou geograficamente, impedindo que ele fosse "infectado" com a cultura europeia, cientificista, individualista e reificante. Isolado, o sertanejo desenvolveu compreensão própria de mundo, formando uma cultura singular só existente no Brasil, traço distintivo de nosso povo.

O romance de formação no Grande sertão é muito mais obscuro em seu poder de alusão. Ele é um romance de formação pessoal do homem integral por meio do gênio romântico, mas também de formação nacional, já que narra um rito de fundação e de passagem que é o pacto, com sua consequente Batalha Final fronteira última entre a criatividade divino-heroica do personagem e o rigor de reflexão racional do narrador. Sua estória dá a entender que a República Velha foi o período de formação da identidade nacional do Brasil, por constituir sua época épica de fundação de uma cultura plural que, com seus híbridos seres singulares, encena o princípio de paródia ao misturar as diferentes culturas do mundo para formar a sua própria.

Conforme se pode extrair da visão rosiana, se o microscosmo reflete o macro pela isomorfia entre todas as camadas (ou equivalência de janelas, como diria Brás Cubas), e o mundo microscópico se desenvolve em concepção divina e heroica, para depois alcançar o equilíbrio racional, então também o universo macroscópico deve seguir essa trajetória. As veredas do sertão rosiano encenam não só a origem do mundo sertanejo, como igualmente representa uma concepção do universo começando nonada do Big Bang e se expandido na violência do ritmo divinoheroico até atingir sua harmonia.

Seu universo é violento como o de Prigogine, com estrelas explodindo em mito a todo o momento, até formar a totalidade dos céus que vemos, com suas luzes de astros mortos há milênios. Esses corpos cósmicos se movimentam caoticamente, chocando-se muitas vezes uns contra os outros, unindo elementos diversamente, formando novos corpos a partir dos que anteriormente colidiram, jorrando estilhaços e magnetismos para todos os lados, até os campos se entrelaçarem, 
formando órbitas mais estáveis, que esses corpos novos percorrem em certo equilíbrio caótico de acaso e necessidade.

Sobre essa constante mutação do mundo e do universo, que, de certo modo, forma a si mesmo, Prigogine avalia que ela não se coaduna ao poder de dominação. A ciência passa a buscar o mesmo movimento que a sociedade: livrar a natureza do poder de dominação e tornar-se "uma ciência do mundo povoado de seres capazes de evoluir, e de inovar, de seres dos quais não podemos, salvo escravizando-os, dar o comportamento previsível e controlável" (1984, p. 207). Querer tornar o mundo estático e imutável, previsível e controlável, significa escravizá-lo. Ainda assim, as coisas não se tornam completamente previsíveis, pois os escravos podem ter comportamentos inesperados, como o Prudêncio de Machado de Assis, que assimilou o comportamento do tirano.

Toda a trama dos sertões euclidianos se passa no embate de dominação entre os elementos naturais, os genes humanos (que em combinações singulares formou as diversas "raças" de brasileiros) e as sociedades humanas. $O$ elemento natural ou racial utilizado como motivo para dominação é refutado pela sugestão dialética. Já a dominação de um ser sobre o outro é encenada numa nova épica de forma trágica, denunciando o martírio das terras e dos homens explorados pelos homens.

O Grande sertão se passa todo na época divino-heroica do poder de mando e comando dos chefes jagunços. Esse poder gera duas guerras com muitas batalhas. Duas guerras são externas e se expressam como demandas épicas, as outras são internas. A primeira demanda épica consiste justamente na linha narrativa euclidiana por excelência do ser tão rosiano, pois se trata da guerra civilizatória de Zé Bebelo contra o sertão supostamente bárbaro. A segunda contenda heroica é a de vingança familiar de Diadorim, trágica e fáustica por excelência, sem excluir o épico e o cômico, contra Hermógenes e Ricardão.

Esse capítulo nos permite interpretar um dos sentidos fundamentais da tensão entre o primitivo e o civilizado nas obras sertanejas. A bifurcação da natureza no sertão de Riobaldo consiste na representação do sertão rústico e antigo como o espaço do poder da intuição, criatividade, imaginação, inovação, engenhosidade dos seres humanos primitivos, encenadas numa aura divina. Já a suposta civilização, imposta indiretamente por Zé Bebelo, consiste na barbárie da busca desenfreada por dinheiro, mesmo que se tenha que explorar o próximo até o limite. O civilizado equivale ao racional e ao cientificismo oficial do fáustico (e, ao mesmo tempo, mefistofélico) interlocutor oculto e o primitivo equivale à criatividade divino-heroica do sertão antigo.

A concepção rosiana talvez seja uma reelaboração, elevada à última potência, da concepção euclidiana do consórcio entre ciência e arte, em consonância com a tensão entre civilização e barbárie. Em Euclides, o historiador irônico questiona constantemente quem é o civilizado e o bárbaro, quem é o primitivo e o moderno, o que é civilização e barbárie. Aqueles supostamente primitivos possuem criatividade e cultura próprias; já os que se consideram civilizados só sabem papagaiar a ciência europeia reificante de sua época, a racionalidade fria da opressão, repressão, exploração, tortura e massacre. Se a visão europeia considera o outro um objeto morto, inanimado, estático e imutável, por que não o explorar?

Não reconhecer o outro como sujeito é sempre muito interessante para qualquer tirano: é o pretexto ideal para promover a exploração. Esse é o tipo de caráter imperial dos personagens machadianos. Em Euclides, o sertanejo primitivo 
representa o sonho e a fantasia que geram uma compreensão própria de mundo, originando culturas e hábitos singulares. Já os litorâneos supostamente civilizados representam o rigor duro da ciência antiga. O narrador de Os sertões sugere que essa tensão dicotômica e destrutiva deveria ser harmônica e cooperativa, formando o moderníssimo consórcio entre fantasia onírica da arte e rigor da reflexão crítica da ciência.

Esse drama sertanejo representa o atrito da ciência clássica com a contemporânea. As tensões sertanejas entre primitivo e civilizado, estático e dinâmico, passivo e ativo, de certa forma, encenam o próprio desenvolvimento da sociedade humana e da ciência. Se a filosofia evoluiu da poesia para a razão fria, assim como os homens passaram da poesia à dicção heroica e daí à racional, agora a ciência tem seu retorno, indo do mundo estático da imutável filosofia metafísica para a poesia da complexidade e diversidade de tudo, como na interpretação de Prigogine:

\begin{abstract}
Tanto ao nível macroscópico como ao nível microscópico, as ciências da natureza libertaram-se, portanto, de uma concepção estreita da realidade objetiva que crê dever negar em seus princípios a novidade e a diversidade, em nome de uma lei universal imutável. Libertaramse de um fascínio que nos representava a racionalidade como coisa fechada, o conhecimento como estando em vias acabadas. Doravante, elas estão abertas à imprevisibilidade, da qual não fazem mais o sinal de um conhecimento imperfeito, de um controle insuficiente. Abriram-se, por isso, ao diálogo com uma natureza que não pode ser dominada mediante um golpe de vista teórico, mas somente explorada, com um mundo aberto ao qual pertencemos e em cuja construção colaboramos (1984, p. 209).
\end{abstract}

Colaboração entre homem e mundo, entre a terra e os seres que a habitam, é justamente o que sugere a visão sertaneja de Euclides da Cunha. O autor já previa a inevitável fusão entre ciência e arte, do mesmo modo que para os antigos pensar era indissociável de poetar. Evolução científica ou retorno modificado? Depende da instância do observador, como advoga a física quântica. Do mesmo modo que o observador itinerante euclidiano e o interlocutor oculto rosiano, também o cientista contemporâneo precisa ser, ao mesmo tempo, ator e espectador da natureza, como avalia Prigogine.

Ele quer renovar a situação do "observador desencarnado" e do "objeto descrito de uma posição de sobrevoo" construída pela ciência clássica. A encenação do plural sertão euclidiano depende da instância do observador itinerante que percorre a terra ignota, rumo ao desconhecido. A aventura científica também se lança ao oculto com suas hipóteses, as quais muitas vezes são derrubadas, mas, outras, confirmadas. Agora, a dinâmica, equiparada com o operador da entropia, nos permite descrever o mundo complexo, para além da superfície. Passamos a ter um mundo povoado de observadores, isto é, de naturezas. A física teórica já pode compreender certas questões filosóficas que se referem à situação do homem no mundo, coisa que a literatura sempre fez. 
Esse diálogo do homem com a natureza implica o consórcio entre ciência e arte, entre rigor de observação, de reflexão crítica, e vigor de imaginação, sonho, fantasia. A arte científica de Euclides da Cunha se processa pelos mesmos princípios da natureza de brotação incessante, numa invenção constante e monumental e de isomorfia entre todas as camadas. Com isso, a terra, o homem e a luta funcionam pelo mesmo princípio de embate dialético entre elementos opostos que tudo forma, conforma, transforma, reforma - intuição intelectual, imaginação ativa.

Quem interpreta o projeto literário euclidiano da união entre rigor de reflexão crítica e vigor de fantasia onírica é José Carlos Barreto de Santana (2001). Ele lembra que na época de Euclides predominava a "reação científica" que se verificava por meio do positivismo, darwinismo, materialismo dialético, spencerismo e determinismo. Embora realize um estudo profícuo, Santana não consegue se desvencilhar da visão da obra euclidiana como impregnada da ciência hegemônica de sua época, como se fosse usada como princípio de composição e não para ironizá-la. Sendo assim, a obra de Euclides teria um viés positivista e determinista.

Euclides acaba ironizando a marcha ascendente linear e contínua da progressão histórica de Augusto Comte, como também todo determinismo naturalista, denunciando ainda que a sociedade não pode funcionar pela seleção do mais forte senão enlouquece, podendo até perder seu sumo, como no caso de Canudos. O consórcio entre ciência e arte estaria em consonância com a mistura de raças e de elementos naturais da América. A obra de Euclides realmente está impregnada das visões científicas de sua época, porém sempre que essas visões aparecem são contestadas pelo narrador numa costura dialética, que mostra que a natureza não pode ser determinada, nem totalmente prevista, pois é aberta, criativa, proliferante, exatamente como o ponto de vista defendido, no fim do século XX, por Prigogine.

Contrariando Santana, avaliamos que as ciências naturais da poética euclidiana se aproximam mais da ciência contemporânea (da qual ele, evidentemente, não poderia ter conhecimento, pois morreu muito antes de sua origem) do que da de sua época. Acabamos de ver, por exemplo, que na concepção dialética de Euclides não só o meio influencia o homem, como também o homem influencia o meio. Tanto o deserto influencia os hábitos, culturas e visões de mundo dos seres humanos, como eles são fazedores de desertos. Prova cabal de que a dialética euclidiana afasta qualquer possibilidade de determinismo.

Em relação ao contraponto dialético às teses vigentes em sua época, podemos nos apoiar num tópico intitulado "Um parêntesis irritante". Esse tópico apresenta um ponto de vista claramente positivista e naturalista, porém o narrador alerta, já no título, que se trata de um parêntesis irritante - que ele abre para demonstrar as visões científicas hegemônicas. Como tais visões são irritantes, não são incorporadas, mas ironizadas por meio de um contraponto dialético no tópico seguinte.

A visão evolucionista e positivista de uma raça superior deve ser vista como um parêntesis irritante e não como a visão de Euclides: "A mistura de raças mui diversas é, na maioria dos casos, prejudicial. Ante as conclusões do evolucionismo, ainda quando reaja sobre o produto o influxo de uma raça superior, despontam vivíssimos estigmas da inferior. A mestiçagem extremada é um retrocesso" (1984, 
p. 62). Depois desse "parêntesis irritante" que fala em raça superior, ele apresenta seu contraponto dialético, segundo o qual "o sertanejo é antes de tudo um forte" (1984, p. 63).

Como diz Sousândrade, o mundo se espanta diante da vitória do mais fraco! Inversão paródica e carnavalesca da teoria darwinista, abolindo as hierarquias. A visão do narrador-personagem parece enaltecer o sertanejo em sua constituição física, moral e cultural, ironizando os meios supostamente avançados: "O abandono em que jazeram teve função benéfica. Libertou-os da adaptação penosíssima a um estádio social superior, e, simultaneamente, evitou que descambassem para as aberrações e vícios dos meios adiantados" (1984, p. 63). A exuberância barroca da criação incessante e a dialética científica que ironiza o ponto de vista monológico da ciência clássica ressoam intensamente nas veredas do sertão rosiano.

Ronaldes de Melo Souza notou a herança sertaneja de Euclides em Guimarães Rosa: "Os sertões e Grande sertão: veredas sinalizam, nos respectivos títulos, a mesma ebriedade dionisíaca da excessividade do sertão. Euclides da Cunha e Guimarães Rosa se irmanam na instituição da poética genuinamente brasileira da terra do homem e do homem da terra" (2009, p. 105). Ronaldes também interpreta o consórcio entre ciência e arte desses autores sertanejos da nossa literatura. $O$ crítico alega o estatuto calculado de vigor da inspiração artística e o rigor científico da reflexão.

Para ele, o projeto do consórcio entre ciência e arte implica um amplo diálogo com os discursos da filosofia e da ciência, descartando sempre o monólogo do especialista, em favor do diálogo com os protagonistas do drama gnosiológico. Ronaldes ressalta ainda que "o fenômeno investigado por meio de múltiplas perspectivas discursivas se revela mais sutilmente estruturado do que o objeto composto pelas leis clássicas do entendimento"; sendo assim, "a inflexão inercial do espírito imobilizado na visão monocular da realidade não se compatibiliza com o projeto multidisciplinar de Euclides da Cunha. O multiperspectivismo interdiscursivo corresponde à irredutível complexidade dos fenômenos observados" (2009, p. 8).

Sobre a suposta adesão euclidiana às visões científicas que vigoravam em sua época, Ronaldes interpreta que o ditame positivista do conhecimento destituído de preconceitos não tem razão. Para ele, a máscara do historiador irônico, além de questionar os preconceitos nacionais acerca da formação do povo brasileiro e da guerra de Canudos, acaba também ironizando as visões científicas vigentes no fim do século XIX e início do XX.

A máscara de investigador dialético também derruba qualquer determinismo e a isomorfia entre as três partes - terra, homem e luta - refuta qualquer possibilidade de progressão linear. Os fragmentos são justapostos descontinuamente, dando saltos ao passado e ao futuro, sem nunca estabelecer um presente fixo. A narrativa fragmentada não possui nenhuma linearidade cronológica, mas segue a observação do narrador em situação narrativa figural, que Ronaldes chama personativa. O leitor só consegue ver para onde aponta a observação do personagem narrador, como uma câmera de cinema, o que estabelece um estilo cinematográfico na poética de Euclides.

Essa tensão interna (entre a cultura científica e a exuberância criativa da natureza) que se reflete na arte de Euclides da Cunha (observador itinerante e 
pintor da natureza telúrica) é projetada como microcosmo interior da batalha exterior entre os homens. A batalha interior diz respeito à solicitação simetricamente oposta entre ciência e arte, no interior do narrador, que tenta casá-las. A guerra externa começa "fria", com a manipulação da mídia, e termina tiranicamente direta no campo de batalha. Na obra euclidiana, o rigor frio da ciência clássica serve de pretexto para "embasar" cinicamente (tergiversar sobre) o massacre de Canudos em sua Batalha Final, retratada com hipocrisia pelos jornais e por uma classe política que se beneficiava da República.

Essa Batalha Final do apocalipse de Canudos remete, em muitos traços, às batalhas medievais do segundo Fausto. A influência de Goethe sobre Euclides é conhecida, mas, em geral, tratada apenas no nível do amor geológico de ambos e suas teorias ousadas a respeito da formação da terra e do planeta; mas essa influência geológica é sobretudo poética e criativa. As batalhas fáusticas e euclidianas ressoam profundamente no Grande sertão de Guimarães Rosa, não só por sua épica tragicômica com tons medievais, mas em todo seu sumo poético. 


\title{
From Euclides da Cunha to Guimarães Rosa: resonances of partnership between science and art in Great Devil In The Whirlwind: Uplands
}

\begin{abstract}
The literary project by Euclides da Cunha comprises in the partnership between science and art, as the author himself told José Veríssimo. This union supposes vigour of poetic imagination structured by scientific strictness such as those quantum particles that involves each other as observed by llya Prigogine. Therefore Cunha's poetic work seems a social history essay. This faustic drama expresses itself in Rosa's Great devil in the whirlwind: uplands in the civilizing fight of Zé Bebelo against poetic and primitive diction of other henchmen led by Joca Ramiro and Hermógenes. The poetic canto of Riobaldo is riddled with philosophical reflections and scientific stringency as his critical disposal of cathartic narrative that intends to heal his own pain of love for Diadorim's death. Through the method of comparative poetics, it intends to demonstrate with a critical-literary and scientific-philosophical basis how Euclides coins the partnership between science and art and its heirship in the work by Rosa.
\end{abstract}

KEYWORDS: Science. Art. Fiction. Literature. 


\section{REFERÊNCIAS}

ATAÍDE, Tristão de. 0 transrealismo de Guimarães Rosa. Rio de Janeiro: Civilização Brasileira; [Brasília]: INL, 1983. (Coleção Fortuna Crítica, v. 6).

COHN, Dorrit. Transparent minds: narrative modes for presenting consciousness in fiction. Princeton, New Jersey: Princeton University Press, 1978.

CUNHA, Euclides da. Correspondência (1890-1909). In: GALVÃO, Walnice Nogueira \& GALOTTI, Oswaldo. Correspondência de Euclides da Cunha. São Paulo: Edusp, 1997.

Os sertões. São Paulo: Três, 1984.

GOETHE, Johann Wolfgang Von. Fausto II. Tradução de Jenny Klabin Segall, apresentação, comentários e notas de Marcus Vinicius Mazzari. São Paulo: 34, 2011.

PRIGOGINE, Ilya. A nova aliança: metamorfose da ciência. Tradução de Miguel Faria e Maria Joaquina Machado Trincheira. Brasília: Editora Universidade de Brasília, 1984.

ROMERO, Emilio. Nuestra tierra. Lima: Casa Nacional de Moneda, 1941.

ROSA, João Guimarães. Grande sertão: veredas. Rio de Janeiro: Nova Fronteira, 2006.

SANTANA, José Carlos Barreto de. Ciência e Arte: Euclides da Cunha e as ciências naturais. São Paulo: Hucitec; [Feira de Santana]: Universidade Estadual de Feira de Santana, 2001.

SOUZA, Ronaldes de Melo e. A geopoética de Euclides da Cunha. Rio de Janeiro: EdUERJ, 2009.

STANZEL, Franz. Narrative situations in the novel (Tom Jones, Mobi-Dick, The Ambassadors, Ulysses). Translated by James P. Pusack. Bloomington/London: Indiana University Press, 1971. 
Recebido: 28 abr. 2016

Aprovado: 28 jan. 2017

DOI: $10.3895 /$ rl.v12n25.3927

Como citar: COSTA, G.M. Ressonâncias do euclidiano consórcio entre ciência e arte no Grande Sertão rosiano. R. Letras, Curitiba, v. 18, n. 23, p. 151-164, jul./dez. 2016. Disponível em: <https://periodicos.utfpr.edu.br/rl>. Acesso em: XXX

Direito autoral: Este artigo está licenciado sob os termos da Licença Creative Commons-Atribuição 4.0 Internacional.

\section{(c) (1)}

